\title{
Association testing of copy number variants in schizophrenia and autism spectrum disorders
}

\author{
Bernard J Crespi ${ }^{*}$ and Helen J Crofts
}

\begin{abstract}
Background: Autism spectrum disorders and schizophrenia have been associated with an overlapping set of copy number variant loci, but the nature and degree of overlap in copy number variants (deletions compared to duplications) between these two disorders remains unclear.

Methods: We systematically evaluated three lines of evidence: (1) the statistical bases for associations of autism spectrum disorders and schizophrenia with a set of the primary CNVs thus far investigated, from previous studies;

(2) data from case series studies on the occurrence of these CNVs in autism spectrum disorders, especially among children, and (3) data on the extent to which the CNVs were associated with intellectual disability and developmental, speech, or language delays. We also conducted new analyses of existing data on these CNVs in autism by pooling data from seven case control studies.

Results: Four of the CNVs considered, dup 1q21.1, dup 15q11-q13, del 16p11.2, and dup 22q11.21, showed clear statistical evidence as autism risk factors, whereas eight CNVs, del 1q21.1, del 3q29, del 15q11.2, del 15q13.3, dup 16p11.2, dup 16p13.1, del 17p12, and del 22q11.21, were strongly statistically supported as risk factors for schizophrenia. Three of the CNVs, dup 1q21.1, dup 16p11.2, and dup 16p13.1, exhibited statistical support as risk factors for both autism and schizophrenia, although for each of these CNVs statistical significance was nominal for tests involving one of the two disorders. For the CNVs that were statistically associated with schizophrenia but were not statistically associated with autism, a notable number of children with the CNVs have been diagnosed with autism or ASD; children with these CNVs also demonstrate a high incidence of intellectual disability and developmental, speech, or language delays.

Conclusions: These findings suggest that although CNV loci notably overlap between autism and schizophrenia, the degree of strongly statistically supported overlap in specific CNVs at these loci remains limited. These analyses also suggest that relatively severe premorbidity to CNV-associated schizophrenia in children may sometimes be diagnosed as autism spectrum disorder.
\end{abstract}

Keywords: Autism, Schizophrenia, Copy Number Variants

\section{Background}

Recent studies of schizophrenia and autism spectrum disorders have generated large suites of data, indicating that each of these disorders is mediated in part by rare copy number variants (CNVs), with substantial overlap in copy number risk loci between the two disorders [1-8]. These data are important because they provide novel insights into both the neurodevelopmental causes of autism spectrum disorders and schizophrenia, and the relationship between the two disorders, a long-standing

\footnotetext{
* Correspondence: crespi@sfu.ca

Department of Biosciences, Simon Fraser University, Burnaby, BC V5A 1 S6, Canada
}

(C) 2012 Crespi and Crofts; licensee BioMed Central Ltd. This is an Open Access article distributed under the terms of the Creative Commons Attribution License (http://creativecommons.org/licenses/by/2.0), which permits unrestricted use, distribution, and reproduction in any medium, provided the original work is properly cited. unresolved issue in psychiatry with direct implications for etiology, diagnosis, the design of research programs, and therapy.

Overlap in copy number loci or variants between schizophrenia and autism spectrum disorders may have several possible causes. First, CNV loci may overlap between the two disorders, but the actual variants associated with each of them, such as deletions versus duplications of the same region, or different specific regions, may vary within and between the two disorders. Examples of genes involved in CNVs for this category include APBA2, CNTNAP2, NRXN1, PARK2, and SHANK3 [9-13]. 
Second, the same CNV may have been reported among individuals with schizophrenia or autism spectrum disorders, or statistically supported as a risk factor for both disorders. Such findings implicate overlapping genetic risk factors and shared etiology, which has been postulated to help explain shared phenotypes, mainly deficits and abnormalities in social development and language. This interpretation, however, runs counter to a large body of non-genetic evidence that differentiates autism spectrum disorders from schizophrenia [14-17], including an exclusionary condition with regard to autism in DSM-IV. How can this apparent incongruity be resolved? One possible explanation is that shared phenotypes of autism spectrum disorders and schizophrenia could be underlain by shared CNV risk factors. This hypothesis has yet to be addressed directly and requires more detailed information on genotypephenotype relations than is currently available. By contrast, an alternative yet non-exclusive hypothesis, originally suggested by Eliez [18] in the context of 22q11.2 deletions, is that for some loci, sharing of CNVs between schizophrenia and autism is more apparent than real, because of false-positive diagnoses of relatively severe, $\mathrm{CNV}$-associated premorbidity to schizophrenia as autism or autism spectrum disorder [19]. The presence of such false positives is predicated on the supposition that autism or autism spectrum disorders and schizophrenia represent distinct conditions with partially overlapping childhood psychological deficits and abnormalities, which are due to different neurodevelopmental causes.

In this article, data from CNV studies of schizophrenia and autism spectrum disorders are used to evaluate alternative hypotheses [20] for the relationship between these disorders that follow from these considerations, and to evaluate the plausibility of the hypothesis of diagnoses of premorbidity to schizophrenia as an autism spectrum disorder in individuals with CNVs. The primary alternative hypotheses considered are: (1) schizophrenia and autism spectrum disorders as conditions that are genetically distinct with regard to their associations with CNVs; and (2) schizophrenia and autism spectrum disorders as overlapping with regard to their associations with CNVs. Such overlap may, however, either be real (a true positive) or only apparent and due substantially to false positive diagnoses of premorbidity to schizophrenia as an autism spectrum disorder. These hypotheses make alternative, more or less exclusive predictions (Table 1) that are evaluated using data from CNVs in these two disorders, and data on other phenotypes and diagnoses associated with the CNVs.

\section{Methods}

CNVs were included for analysis if they met three criteria: (1) previous evidence for statistical association of the CNV with schizophrenia, autism, or both disorders; (2) reports of the CNV in both conditions, from case control, family-based, or case series studies (CNV studies based on ascertainment of a range of childhood conditions, followed by focused analysis on one or more specific CNVs); and (3) sufficient information on phenotypes associated with the CNVs, especially intellectual disability and developmental, speech or language delay, to assess its effects on childhood development, bearing in mind how individuals were ascertained.

Genomic coordinates of the CNVs considered here were defined as in the salient publications (e.g., [21]) and as described below. A pooled analysis was also conducted to test for the focal CNVs as statistically based autism risk factors; this analysis included data from all CNV studies that focused on autism, across multiple loci, using case control or case unaffected sibling designs: Table 1 in Sebat et al. [22], Supplementary Table 2 in Szatmari et al. [23], Table S2 in Christian et al. [24], Table 3 in Marshall et al. [25], Table 1 and pers. comm. in Glessner et al. [26], Supplementary Tables 2, 6, and 8 in Pinto et al. [27], and Table 3 in Sanders et al. [28]. Overlap among studies in autism cases for the AGRE and the AGP data was accounted for in discernment of cases and analysis (i.e., autism and autism spectrum individuals with a given $\mathrm{CNV}$ were counted only once). Overall, this analysis included 5,530 cases and 7190 controls. Any overlap between studies in probands who did not harbor CNVs would bias case control analyses against rejection of the null hypothesis (of no association), and thus render the tests performed more conservative. Additional caveats regarding the pooled case control analysis for autism conducted here, and the results from other authors presented in Table 2, include the lack of report of all observed CNVs in some studies [26], possible unobserved overlap among individuals in control groups, and the uses of different technology platforms of varying sensitivities for $\mathrm{CNV}$ detection and analysis.

\section{Results}

Four of the CNVs, dup 1q21.1, dup 15q11-q13, del 16p11.2, and dup 22q11.21, show clear statistical evidence as autism risk factors, whereas the other eight CNVs considered here, del 1q21.1, del 3q29, del 15q11.2, del 15q13.3, dup 16p11.2, dup 16p13.1, del 17p12, and del 22q11.21, are well supported as risk factors for schizophrenia (Table 2). Three CNVs, dup 1q21.1, dup 16p11.2, and dup16p13.1, exhibit statistical support as risk factors for both autism and schizophrenia, although in each case statistical significance is nominal for one of the two conditions (dup 1q21.1 in schizophrenia, $p=0.02$; dup 16p11.2 in autism, $p=0.025$ in the pooled case control analysis; dup 16p13.1 in autism, $p=0.023$ in 


\begin{tabular}{|c|c|c|c|}
\hline \multicolumn{4}{|c|}{ MODEL 1: AUTISM or ASD and schizophrenia as separate disorders } \\
\hline \multicolumn{4}{|l|}{ MODEL 1a: AUTISM OR ASD ONLY } \\
\hline & Child & Adult & Comments \\
\hline CNV is autism risk factor only & Autism or ASD & $\begin{array}{l}\text { Autism or ASD; no } \\
\text { schizophrenia }\end{array}$ & $\begin{array}{l}\text { ASD traits, but no schizophrenia } \\
\text { spectrum traits, in adults }\end{array}$ \\
\hline \multicolumn{4}{|l|}{ MODEL 1b: SCHIZOPHRENIA ONLY } \\
\hline & Child & Adult & Comments \\
\hline CNV is schizophrenia risk factor & $\begin{array}{l}\text { Non-clinical or mild } \\
\text { premorbidity; no autism or ASD }\end{array}$ & $\begin{array}{l}\text { Schizophrenia; } \\
\text { no autism or ASD }\end{array}$ & $\begin{array}{l}\text { Possibe schizophrenia spectrum } \\
\text { traits in individuals with CNV but } \\
\text { no schizophrenia diagnosis }\end{array}$ \\
\hline \multicolumn{4}{|c|}{ MODEL 2: ASD and schizophrenia as apparently overlapping disorders } \\
\hline \multicolumn{4}{|c|}{ MODEL 2a: AUTISM OR ASD AND SCHIZOPHRENIA; TRUE OVERLAP } \\
\hline & Child & Adult & Comments \\
\hline $\begin{array}{l}\text { CNV is risk factor for both autism or } \\
\text { ASD and schizophrenia }\end{array}$ & Autism or ASD & $\begin{array}{l}\text { Schizophrenia or } \\
\text { autism or ASD }\end{array}$ & $\begin{array}{l}\text { Traits overlapping ASD, autism and } \\
\text { schizophrenia, such as sociality and } \\
\text { language deficits/abnormalities, are } \\
\text { prominent }\end{array}$ \\
\hline \multicolumn{4}{|c|}{ MODEL 2b: SCHIZOPHRENIA ONLY; AUTISM OR ASD IS FALSE POSITIVE } \\
\hline & Child & Adult & Comments \\
\hline $\begin{array}{l}\text { CNV is schizophrenia risk factor only; autism } \\
\text { or ASD diagnoses are false positives }\end{array}$ & $\begin{array}{l}\text { 'Autism or ASD' (actually } \\
\text { premorbidity to schizophrenia) }\end{array}$ & $\begin{array}{l}\text { Schizophrenia; } \\
\text { no autism or ASD }\end{array}$ & $\begin{array}{l}\text { 'ASD' children have adult relatives with } \\
\text { schizophrenia or schizophrenia spectrum; } \\
\text { 'ASD' is commonly PDD-NOS; child 'ASD' } \\
\text { phenotypes resemble schizophrenia } \\
\text { premorbid phenotypes that are relatively } \\
\text { severe }\end{array}$ \\
\hline
\end{tabular}

the analysis by Table 2 in Hannes et al. [49]). Details regarding all of the relevant studies, for each $\mathrm{CNV}$ locus, are presented in Additional file 1.

For all of the CNV risk factors for schizophrenia, case reports and case series demonstrate that multiple children with the CNV have been diagnosed with autism, ASD, autistic features, intellectual disability, developmental, speech, or language delays, and/or multiple congenital anomalies (Table 2 and Additional file 1). Such case studies have generally not, however, evaluated the statistical significance of the $\mathrm{CNV}$ as an autism spectrum condition risk factor.

\section{Discussion}

With regard to the predictions of the different models in Table 1, three autism-associated CNVs, dup 15q11q13, del 16p11.2, and dup 22q11.21, appear to fit with Model 1a, in that very few or no cases of schizophrenia have been reported among individuals with these $\mathrm{CNVs}$ and they show a lack of statistical evidence of being schizophrenia risk factors. Evidence regarding the associations of three CNVs, dup 1q21.1, dup $16 \mathrm{p} 11.2$, and dup 16p13.1, with autism and schizophrenia risk suggests that they may fit with Model 2a of true overlap, although the nominal nature of one of the statistical associations, for each $\mathrm{CNV}$, indicates that additional data are needed for robust interpretation and exclusion of Model 2b. In addition, for dup 16p13.1, evidence of an association with autism comes from a single analysis that includes only three autism cases with the CNV [49], whereas analysis of the pooled data from seven case control studies provides no evidence of association.

The largest number of CNVs (deletions of 1q21.1, $3 q 29,15 q 11.2,15 q 13.3,17 \mathrm{p} 12$, and 22q11.2) appears to fit Model 2b of schizophrenia risk with possible falsepositive diagnoses of ASDs in childhood. Such putative false-positive interpretations are based on a combination of four lines of evidence: (1) strong statistical evidence from studies of schizophrenia for the CNV as a risk factor in this disorder; (2) reports of the CNV in some individuals with ASD from large-scale, case control CNV studies of ASD or autism, but with lack of its documentation as a statistically based risk factor for ASD or autism from case control studies; (3) reports of the CNV in ASD or autism cases from case series and case reportbased studies that are designed and presented in nonstatistical contexts; and (4) the presence, among children with the CNV, of a high frequency of some combination of intellectual disability, developmental delay, or speech or language delay [72], conditions that may represent manifestations of premorbidity to schizophrenia that can contribute to ascertainment and diagnoses of ASDs in children $[18,73,74]$. 
Table 2 Data on statistical significance, numbers of cases (in boldface parentheses), and case descriptions, for CNVs that have been reported in both autism and schizophrenia

\begin{tabular}{|c|c|c|c|c|c|c|c|}
\hline CNV & $\begin{array}{l}\text { Number } \\
\text { autism } \\
\text { \# cases (refs) }^{1}\end{array}$ & $\begin{array}{l}\text { Number } \\
\text { controls } \\
\text { \# cases (refs) }^{1}\end{array}$ & $\begin{array}{l}p \text {, autism risk, } \\
\text { pooled data' }\end{array}$ & $\begin{array}{l}\text { p, autism risk, } \\
\text { prev. studies } \\
\text { (\# cases) (refs) }\end{array}$ & $\begin{array}{l}\text { p, schizo. risk, } \\
\text { prev. studies } \\
\text { (\# cases) (refs) }{ }^{2}\end{array}$ & $\begin{array}{l}\text { Autism, ASD, ID, } \\
\text { delays, in case } \\
\text { reports, series (refs) }\end{array}$ & $\begin{array}{l}\text { Model } \\
\text { supported }\end{array}$ \\
\hline del 1q21.1 & $1[23]$ & 0 & 0.43 & $0.029(\mathbf{1})[4,29]$ & $8.5 \times 10^{-6}(\mathbf{2 0})[30]$ & Yes $[29,31]$ & $2 b$ \\
\hline dup 1q21.1 & $7[23,27,28]$ & 0 & 0.0029 & $9 \times 10^{-5}(\mathbf{3})[4,29]$ & $0.02(\mathbf{1 1})[30]$ & Yes $[29,31]$ & $2 a$ or $2 b$ \\
\hline del 3q29 & $1[28]$ & 0 & 0.43 & & $0.0004(\mathbf{7})[30]$ & Yes [32-34] & $2 b$ \\
\hline del $15 q 11.2$ & $2[27]$ & 0 & 0.19 & & $4.46 \times 10^{-8}(\mathbf{4 9})[3]$ & Yes [35-38] & $2 b$ \\
\hline $\begin{array}{l}\text { dup 15q11-q13 } \\
\text { (BP2-BP3) }\end{array}$ & $20[23,24$ 26-28] & 0 & $<0.0001$ & $\begin{array}{l}4 \times 10^{-4},(\mathbf{6})[28] ; \\
1 \times 10^{-5},(\mathbf{1 3})[26]\end{array}$ & $0.10(\mathbf{2})[7]$ & Yes $[7,39,40]$ & $1 a$ \\
\hline del $15 q 13.3$ & $3[27,28]$ & 0 & 0.082 & & $6.9 \times 10^{-7}(\mathbf{2 1})[30]$ & Yes [41-43] & $2 b$ \\
\hline del 16p11.2 & $15[22,25-28]$ & $4(26)$ & 0.0015 & $\begin{array}{l}5 \times 10^{-29}(\mathbf{1 4})[28] \\
0.044(\mathbf{4})[44]\end{array}$ & $0.88(\mathbf{4})[30]$ & Yes [45-48] & $1 \mathrm{a}$ \\
\hline dup 16p11.2 & 10 [25-28] & $4(26)$ & 0.0246 & $2 \times 10^{-5}(\mathbf{5})[28]$ & $2.6 \times 10^{-8}(\mathbf{3 1})[30]$ & Yes $[45,47]$ & $2 a$ or $2 b$ \\
\hline dup 16p13.1 & 0 & 0 & ns & $0.023(\mathbf{3})[49]$ & $0.00001(\mathbf{1 2})[50]$ & Yes $[49,51,52]$ & $2 a$ or $2 b$ \\
\hline del 17p12 & $2[28]$ & 0 & 0.19 & $0.58,0.14(\mathbf{5})[53]^{4}$ & $0.0147(\mathbf{4})[53]$ & Yes [53-55] & $2 b$ \\
\hline del 22q11.21 & $2[27,28]$ & 0 & 0.19 & $0.11(\mathbf{3})[28]$ & $7.3 \times 10^{-13}(\mathbf{3 5})[30]$ & Yes [19,56-62] & $2 b$ \\
\hline dup 22q11.21 & 9 [24-27] & 0 & 0.00055 & $0.0218(\mathbf{5})[26]$ & $\begin{array}{l}\text { Not tested in [4] or } \\
\text { [30]; too few cases } \\
\text { of schizophrenia }\end{array}$ & Yes [63-70] & $1 \mathrm{a}$ \\
\hline
\end{tabular}

See Additional file 1 for details.

${ }^{1}$ Case control data from Sebat et al. [22], Szatmari et al. [23], Christian et al. [24], Marshall et al. [25], Glessner et al. [26], Pinto et al. [27], and Sanders et al. [28]. Details are provided in Additional file 1.

Fisher's exact test was used.

${ }^{2}$ Most recent analysis, meta-analysis, or pooled-data analysis.

${ }^{3}$ Details of these studies are provided in Additional file 1. See also Cooper et al. [71], Kaminsky et al. [21], and Sahoo et al. [72]. "Yes" refers to the presence of autism, ASD, or 'autistic features' among one or more individuals in these reports.

${ }^{4}$ Tests involve autism cases only, discovery and follow-up samples. See Additional file 1 for details.

Diagnoses of premorbidity to schizophrenia as autism spectrum disorder might be expected in CNV studies for several additional reasons, from previous studies:

1. Schizophrenia involves well-documented premorbidity, in a substantial proportion of cases, which centers on developmental, social, and language deficits [75-78]. In children, premorbidity to schizophrenia most commonly involves 'negative' symptoms including deficits in social interaction $[79,80]$, which can overlap with symptoms of autism spectrum disorders [81-85]. Mild to borderline intellectual disability in individuals with schizophrenia is also associated with a higher incidence of negative, compared to positive, symptoms by meta-analysis [86], although this study did not consider effects on premorbid phenotypes. Most of the overlap in symptoms between ASDs and schizophrenia premorbidity appears to involve deficits, delays, or generalized abnormalities, rather than the definitive presence of specific biological or psychological phenotypes. Among all autism spectrum disorders, PDD-NOS is the most commonly diagnosed $[87,88]$. Such cases usually fail to reach the threshold for autism because of lack of fit to the criteria for restricted interests and repetitive behavior [89], which is also the ASD criterion least likely to be represented in premorbidity to schizophrenia. Premorbidity to schizophrenia is also more severe among males than females $[11,80,90]$, which is concordant with the strong male bias found in autism spectrum disorders [91];

2. Compared to disease-associated SNPs, diseaseassociated CNVs tend to be rare, more-highly penetrant, syndromic genetic risk factors [8,92,93]. Their deleterious effects on early neurodevelopment might thus be expected to be relatively severe, such that childhood premorbidity, for individuals with schizophrenia-risk CNVs, might be especially prevalent and pronounced compared to individuals without schizophrenia-risk CNVs. A recent study by Sahoo et al. [72] provides evidence consistent with such premorbidity, in that of 38,779 individuals (predominantly children) referred mainly for developmental delay, intellectual disability, autism spectrum disorders, or multiple congenital anomalies, 704 exhibited one of seven CNVs (del 1q21.1, dup 1q21.1, del 15q11.2, del 15q13.3, dup 16p11.2, dup 16p13.11, or del 22q11.2) that has been statistically associated with schizophrenia in studies of adults [30,50]. 
3. Numerous cases have been reported in the literature of individuals diagnosed with autism spectrum disorders in early to middle childhood, and schizophrenia in late childhood, adolescence, or early adulthood [11,94-100]. Despite these associations, individuals with ASD are apparently not at overall higher risk of later developing schizophrenia [101,102]. Moreover, autism and ASD tend to show familial aggregation of their diagnoses and phenotypes [16,103-105], largely separate from the strong familial aggregation found for schizophrenia [106-108]. A simple hypothesis for explaining these findings would be that sequential diagnoses in the same individuals of ASD (in childhood) and schizophrenia (in adulthood) are sometimes mediated by rare, penetrant schizophrenia risk factors (such as CNVs) that cause relatively severe premorbidity [11]. Direct evidence regarding this hypothesis comes from Addington and Rapoport [109], who showed that individuals with childhood-onset schizophrenia mediated by schizophrenia-associated CNVs were more likely to exhibit premorbidity to schizophrenia in the form of developmental delays $(p=0.0001)$ and may have been more likely to exhibit diagnoses of a PDD $(p=0.10)$ compared to such children lacking these CNVs. Additional evidence comes from studies by Ingason et al. [7] and Chen et al. [110], who each reported sequential diagnoses of autism spectrum disorder in childhood and schizophrenia in adulthood among an individual with such alterations (respectively, a duplication of 15q11-q13 and a balanced translocation disrupting GNB1L, a gene in the 22q11.2 deletion region).

Evaluation of whether ASD diagnoses represent false positives for individuals with schizophrenia-associated CNVs would require longitudinal studies of the individuals involved. Resolution of this question would also benefit from studies of non-clinical individuals bearing risk CNVs, analyses of autism and schizophrenia endophenotypes among individuals with risk CNVs, and studies that focus on the differential diagnosis of autism spectrum disorders in relation to schizophrenia premorbidity in children [11,111-117].

An alternative interpretation to the false-positive hypothesis for diagnoses of ASD among children with schizophrenia-associated CNVs is that such ASD diagnoses are true positives that are compatible with possible later diagnoses of the same individual with schizophrenia $[56,99]$. Under this interpretation, diagnoses of ASD in children who develop schizophrenia as adolescents or adults would reflect developmental stages, with schizophrenia as the final pathway [118]. By contrast, other
ASD cases would fit the classic criteria derived from Kanner [119], Asperger [120], and Rutter [16,17,121], which consider autism as a lifelong condition present from early childhood. Whether or not childhood premorbidity to schizophrenia should be considered an ASD remains an open question, the resolution of which depends in part on the degree to which the causes and phenotypes of ASD in schizophrenia premorbidity overlap with the causes and phenotypes of other cases of ASD.

\section{Conclusions}

One of the primary implications of these results is that hypotheses of autism and schizophrenia sharing substantial genetic etiology with regard to specific CNVs are not strongly supported by the empirical data, and appear to be based in large part on non-statistical evidence from case reports and case series, combining of duplications with deletions for statistical analyses, very small numbers of cases, or pooling of autism or ASD with other diagnoses (such as developmental delay or intellectual disability), which prevents inference concerning which, if any, of the conditions are associated with the focal CNV $[1,28,53,122,123]$. Additional studies that focus strictly on autism or ASD and schizophrenia for specific CNVs, that take account of childhood premorbidity to schizophrenia as a possible confounding factor, should help to clarify the relationship between these disorders.

\section{Additional file}

Additional file 1: Association testing of copy number variants in schizophrenia and autism spectrum disorders.

Competing interests

The authors declare that they have no competing interests.

\section{Acknowledgements}

We are grateful to two anonymous reviewers for helpful comments.

\section{Authors' Contributions}

$\mathrm{BC}$ conceived the study and wrote the bulk of the manuscript, and HJC organized and compiled relevant CNV data, and helped in assembling and editing the manuscript. All authors read and approved the final manuscript.

Received: 6 January 2012 Accepted: 30 May 2012 Published: 30 May 2012

\section{References}

1. McCarthy SE, Makarov V, Kirov G, Addington AM, McClellan J, Yoon S, Perkins DO, Dickel DE, Kusenda M, Krastoshevsky O, Krause V, Kumar RA, Grozeva D, Malhotra D, Walsh T, Zackai EH, Kaplan P, Ganesh J, Krantz ID, Spinner NB, Roccanova P, Bhandari A, Pavon K, Lakshmi B, Leotta A, Kendall J, Lee YH, Vacic V, Gary S, lakoucheva LM, Crow TJ, et al: Microduplications of 16p11.2 are associated with schizophrenia. Nat Genet 2009, 41 (11):1223-1227.

2. Guilmatre A, Dubourg C, Mosca AL, Legallic S, Goldenberg A, DrouinGarraud V, Layet V, Rosier A, Briault S, Bonnet-Brilhault F, Laumonnier F, Odent S, Le Vacon G, Joly-Helas G, David V, Bendavid C, Pinoit JM, Henry C, 
Impallomeni C, Germano E, Tortorella G, Di Rosa G, Barthelemy C, Andres C, Faivre L, Frébourg T, Saugier Veber P, Campion D: Recurrent rearrangements in synaptic and neurodevelopmental genes and shared biologic pathways in schizophrenia, autism, and mental retardation. Arch Gen Psychiatry 2009, 66:947-956.

3. Kirov G, Grozeva D, Norton N, Ivanov D, Mantripragada KK, Holmans P, et al: Support for the involvement of large copy number variants in the pathogenesis of schizophrenia. Hum Mol Genet 2009, 18(8):1497-1503.

4. Crespi B, Stead P, Elliot M: Comparative genomics of autism and schizophrenia. Proc Natl Acad Sci U S A 2010, 107(Suppl 1):1736-1741

5. Kooy RF: Distinct disorders affecting the brain share common genetic origins. F1000 Biol Rep 2010, 2:11. pii.

6. Mulle JG, Dodd AF, McGrath JA, Wolyniec PS, Mitchell AA, Shetty AC, Sobreira NL, Valle D, Rudd MK, Satten G, Cutler DJ, Pulver AE, Warren ST: Microdeletions of $3 q 29$ confer high risk for schizophrenia. Am J Hum Genet 2010, 87(2):229-236.

7. Ingason A, Kirov G, Giegling I, Hansen T, Isles AR, Jakobsen KD, Kristinsson KT, le Roux L, Gustafsson O, Craddock N, Möller HJ, McQuillin A, Muglia P, Cichon S, Rietschel M, Ophoff RA, Djurovic S, Andreassen OA, Pietiläinen OP, Peltonen L, Dempster E, Collier DA, St Clair D, Rasmussen HB, Glenthøj BY, Kiemeney LA, Franke B, Tosato S, Bonetto C, Saemundsen E, et al: Maternally derived microduplications at 15q11-q13: implication of imprinted genes in psychotic illness. Am J Psychiatry 2011, 168(4):408-417.

8. Malhotra D, Sebat J: CNVs: Harbingers of a rare variant revolution in psychiatric genetics. Cell 2012, 148:1223-1241.

9. Kirov G, Gumus D, Chen W, Norton N, Georgieva L, Sari M, O'Donovan MC, Erdogan F, Owen MJ, Ropers HH, Ullmann R: Comparative genome hybridization suggests a role for NRXN1 and APBA2 in schizophrenia. Hum Mol Genet 2008, 17:458-465.

10. Kirov G, Rujescu D, Ingason A, Collier DA, O'Donovan MC, Owen MJ: Neurexin 1 (NRXN1) deletions in schizophrenia. Schizophr Bull 2009, 35:851-854.

11. Rapoport J, Chavez A, Greenstein D, Addington A, Gogtay N: Autism spectrum disorders and childhood-onset schizophrenia: clinical and biological contributions to a relation revisited. J Am Acad Child Adolesc Psychiatr 2009, 48(1):10-18.

12. Babatz TD, Kumar RA, Sudi J, Dobyns WB, Christian SL: Copy number and sequence variants implicate APBA2 as an autism candidate gene. Autism Res 2009, 2:359-364.

13. Gauthier J, Siddiqui TJ, Huashan P, Yokomaku D, Hamdan FF, Champagne N, Lapointe M, Spiegelman D, Noreau A, Lafrenière RG, Fathalli F, Joober R, Krebs MO, DeLisi LE, Mottron L, Fombonne E, Michaud JL, Drapeau P, Carbonetto S, Craig AM, Rouleau GA: Truncating mutations in NRXN2 and NRXN1 in autism spectrum disorders and schizophrenia. Hum Genet 2011, 130:563-573.

14. Kolvin I: Studies in the childhood psychoses. I. Diagnostic criteria and classification. Br J Psychiatry 1971, 118:381-384.

15. Kolvin I, Ounsted C, Humphrey M, McNay A: Studies in the childhood psychoses. II. The phenomenology of childhood psychoses. Br J Psychiatry 1971, 118:385-395.

16. Rutter M: Concepts of autism: a review of research. J Child Psychol Psychiatry 1968, 9:1-25.

17. Rutter M: Relationships between child and adult psychiatric disorders. Some research considerations. Acta Psychiatr Scand 1972, 48:3-21.

18. Eliez S: Autism in children with 22q11.2 deletion syndrome. J Am Acad Child Adolesc Psychiatr 2007, 46(4):433-434.

19. Feinstein $C$, Singh S: Social phenotypes in neurogenetic syndromes. Child Adolesc Psychiatr Clin N Am 2007, 16(3):631-647.

20. Cannon TD: What is the role of theories in the study of schizophrenia? Schizophr Bull 2009, 35:563-567.

21. Kaminsky EB, Kaul V, Paschall J, Church DM, Bunke B, Kunig D, Moreno-DeLuca D, Moreno-De-Luca A, Mulle JG, Warren ST, Richard G, Compton JG, Fuller AE, Gliem TJ, Huang S, Collinson MN, Beal SJ, Ackley T, Pickering DL, Golden DM, Aston E, Whitby H, Shetty S, Rossi MR, Rudd MK, South ST, Brothman AR, Sanger WG, lyer RK, Crolla JA, Thorland EC, Aradhya S, Ledbetter DH, Martin CL: $\mathrm{n}$ evidence-based approach to establish the functional and clinical significance of copy number variants in intellectual and developmental disabilities. Genet Med 2011, 9:777-784.

22. Sebat J, Lakshmi B, Malhotra D, Troge J, Lese-Martin C, Walsh T, Yamrom B, Yoon S, Krasnitz A, Kendall J, Leotta A, Pai D, Zhang R, Lee YH, Hicks J, Spence SJ, Lee AT, Puura K, Lehtimäki T, Ledbetter D, Gregersen PK,
Bregman J, Sutcliffe JS, Jobanputra V, Chung W, Warburton D, King MC, Skuse D, Geschwind DH, Gilliam TC, et al: Strong association of de novo copy number mutations with autism. Science 2007, 316(5823):445-449.

23. Szatmari P, Paterson AD, Zwaigenbaum L, Roberts W, Brian J, Liu XQ, Vincent JB, Skaug JL, Thompson AP, Senman L, Feuk L, Qian C, Bryson SE, Jones MB, Marshall CR, Scherer SW, Vieland VJ, Bartlett C, Mangin LV, Goedken R, Segre A, Pericak-Vance MA, Cuccaro ML, Gilbert JR, Wright HH, Abramson RK, Betancur C, Bourgeron T, Gillberg C, Leboyer M, et al: Mapping autism risk loci using genetic linkage and chromosomal rearrangements. Nat Genet 2007, 39:319-328.

24. Christian SL, Brune CW, Sudi J, Kumar RA, Liu S, Karamohamed S, Badner JA, Matsui S, Conroy J, McQuaid D, Gergel J, Hatchwell E, Gilliam TC, Gershon ES, Nowak NJ, Dobyns WB, Cook EH Jr: Novel submicroscopic chromosomal abnormalities detected in autism spectrum disorder. Biol Psychiatry 2008, 63(12):1111-1117.

25. Marshall CR, Noor A, Vincent JB, Lionel AC, Feuk L, Skaug J, Shago M, Moessner R, Pinto D, Ren Y, Thiruvahindrapduram B, Fiebig A, Schreiber S, Friedman J, Ketelaars CE, Vos YJ, Ficicioglu C, Kirkpatrick S, Nicolson R, Sloman L, Summers A, Gibbons CA, Teebi A, Chitayat D, Weksberg R, Thompson A, Vardy C, Crosbie V, Luscombe S, Baatjes R, et al: Structural variation of chromosomes in autism spectrum disorder. Am J Hum Genet 2008, 82(2):477-488.

26. Glessner JT, Wang K, Cai G, Korvatska O, Kim CE, Wood S, Zhang H, Estes A, Brune CW, Bradfield JP, Imielinski M, Frackelton EC, Reichert J, Crawford EL, Munson J, Sleiman PM, Chiavacci R, Annaiah K, Thomas K, Hou C, Glaberson W, Flory J, Otieno F, Garris M, Soorya L, Klei L, Piven J, Meyer KJ, Anagnostou E, Sakurai T, et al: Autism genome-wide copy number variation reveals ubiquitin and neuronal genes. Nature 2009, 459 (7246):569-573.

27. Pinto D, Pagnamenta AT, Klei L, Anney R, Merico D, Regan R, Conroy J, Magalhaes TR, Correia C, Abrahams BS, Almeida J, Bacchelli E, Bader GD, Bailey AJ, Baird G, Battaglia A, Berney T, Bolshakova N, Bölte S, Bolton PF, Bourgeron T, Brennan S, Brian J, Bryson SE, Carson AR, Casallo G, Casey J, Chung BH, Cochrane L, Corsello C, et al: Functional impact of global rare copy number variation in autism spectrum disorders. Nature 2010, 466 (7304):368-372.

28. Sanders SJ, Ercan-Sencicek AG, Hus V, Luo R, Murtha MT, Moreno-De-Luca D, Chu SH, Moreau MP, Gupta AR, Thomson SA, Mason CE, Bilguvar K, Celestino-Soper PB, Choi M, Crawford EL, Davis L, Wright NR, Dhodapkar RM, DiCola M, DiLullo NM, Fernandez TV, Fielding-Singh V, Fishman DO, Frahm S, Garagaloyan R, Goh GS, Kammela S, Klei L, Lowe JK, Lund SC, et al: Multiple recurrent de novo CNVs, including duplications of the 7q11.23 Williams syndrome region, are strongly associated with autism. Neuron 2011, 70(5):863-885.

29. Mefford HC, Sharp AJ, Baker C, Itsara A, Jiang Z, Buysse K, Huang S, Maloney VK, Crolla JA, Baralle D, Collins A, Mercer C, Norga K, de Ravel T, Devriendt K, Bongers EM, de Leeuw N, Reardon W, Gimelli S, Bena F, Hennekam RC, Male A, Gaunt L, Clayton-Smith J, Simonic I, Park SM, Mehta SG, Nik-Zainal S, Woods CG, Firth HV, et al: Recurrent rearrangements of chromosome 1q21.1 and variable pediatric phenotypes. N Engl J Med 2008, 359 (16):1685-1699.

30. Levinson DF, Duan J, Oh S, Wang K, Sanders AR, Shi J, Zhang N, Mowry BJ, Olincy A, Amin F, Cloninger CR, Silverman JM, Buccola NG, Byerley WF, Black DW, Kendler KS, Freedman R, Dudbridge F, Pe'er I, Hakonarson H, Bergen SE, Fanous AH, Holmans PA, Gejman PV: Copy number variants in schizophrenia: confirmation of five previous findings and new evidence for 3q29 microdeletions and VIPR2 duplications. Am J Psychiatry 2011, 168(3):302-316.

31. Brunetti-Pierri N, Berg JS, Scaglia F, Belmont J, Bacino CA, Sahoo T, Lalani SR, Graham B, Lee B, Shinawi M, Shen J, Kang SH, Pursley A, Lotze T, Kennedy G, Lansky-Shafer S, Weaver C, Roeder ER, Grebe TA, Arnold GL, Hutchison T, Reimschisel T, Amato S, Geragthy MT, Innis JW, Obersztyn E, Nowakowska B, Rosengren SS, Bader PI, Grange DK, et al: Recurrent reciprocal 1q21.1 deletions and duplications associated with microcephaly or macrocephaly and developmental and behavioral abnormalities. Nat Genet 2008, 40(12):1466-1471. 32

32. Willatt L, Cox J, Barber J, Cabanas ED, Collins A, Donnai D, FitzPatrick DR, Maher E, Martin H, Parnau J, Pindar L, Ramsay J, Shaw-Smith C, Sistermans EA, Tettenborn M, Trump D, de Vries BB, Walker K, Raymond FL: 3q29 microdeletion syndrome: clinical and molecular characterization of a new syndrome. Am J Hum Genet 2005, 77(1):154-160. 
33. Ballif BC, Theisen A, Coppinger J, Gowans GC, Hersh JH, Madan-Khetarpal S, Schmidt KR, Tervo R, Escobar LF, Friedrich CA, McDonald M, Campbell L, Ming JE, Zackai EH, Bejjani BA, Shaffer LG: Expanding the clinical phenotype of the $3 q 29$ microdeletion syndrome and characterization of the reciprocal microduplication. Mol Cytogenet 2008, 1:8

34. Clayton-Smith J, Giblin C, Smith RA, Dunn C, Willatt L: Familial 3q29 microdeletion syndrome providing further evidence of involvement of the 3q29 region in bipolar disorder. Clin Dysmorphol 2010, 19(3):128-132

35. Murthy SK, Nygren AO, El Shakankiry HM, Schouten JP, Al Khayat Al, Ridha A, Al Ali MT: Detection of a novel familial deletion of four genes between BP1 and BP2 of the Prader-Willi/Angelman syndrome critical region by oligo-array CGH in a child with neurological disorder and speech impairment. Cytogenet Genome Res 2007, 116(1-2):135-140.

36. Doornbos M, Sikkema-Raddatz B, Ruijvenkamp CA, Dijkhuizen T, Bijlsma EK, Gijsbers AC, Hilhorst-Hofstee Y, Hordijk R, Verbruggen KT, Kerstjens-Frederikse WS, van Essen T, Kok K, van Silfhout AT, Breuning M, van Ravenswaaij-Arts CM: Nine patients with a microdeletion $15 q 11.2$ between breakpoints 1 and 2 of the Prader-Willi critical region, possibly associated with behavioural disturbances. Eur J Med Genet 2009, 52(2-3):108-115.

37. Burnside RD, Pasion R, Mikhail FM, Carroll AJ, Robin NH, Youngs EL, Gadi IK, Keitges E, Jaswaney VL, Papenhausen PR, Potluri VR, Risheg H, Rush B, Smith JL, Schwartz S, Tepperberg JH, Butler MG: Microdeletion/microduplication of proximal $15 q 11.2$ between BP1 and BP2: a susceptibility region for neurological dysfunction including developmental and language delay. Hum Genet 2011, 130:517-528.

38. von der Lippe C, Rustad C, Heimdal K, Rødningen OK: $15 q 11.2$ microdeletion - seven new patients with delayed development and/or behavioural problems. Eur J Med Genet 2011, 54(3):357-360.

39. Bolton PF, Dennis NR, Browne CE, Thomas NS, Veltman MW, Thompson RJ, Jacobs $P$ : The phenotypic manifestations of interstitial duplications of proximal $15 q$ with special reference to the autistic spectrum disorders. Am J Med Genet 2001, 105(8):675-685.

40. Hogart A, Wu D, LaSalle JM, Schanen NC: The comorbidity of autism with the genomic disorders of chromosome 15q11.2-q13. Neurobiol Dis 2010, 38(2):181-191.

41. van Bon BW, Mefford HC, Menten B, Koolen DA, Sharp AJ, Nillesen WM, Innis JW, de Ravel TJ, Mercer CL, Fichera M, Stewart H, Connell LE, Ounap K, Lachlan K, Castle B, Van der Aa N, van Ravenswaaij C, Nobrega MA, SerraJuhé C, Simonic I, de Leeuw N, Pfundt R, Bongers EM, Baker C, Finnemore $P$, Huang S, Maloney VK, Crolla JA, van Kalmthout M, Elia M, et al: Further delineation of the $15 q 13$ microdeletion and duplication syndromes: a clinical spectrum varying from non-pathogenic to a severe outcome. J Med Genet 2009, 46(8):511-523.

42. Ben-Shachar S, Lanpher B, German JR, Qasaymeh M, Potocki L, Nagamani SC, Franco LM, Malphrus A, Bottenfield GW, Spence JE, Amato S, Rousseau JA, Moghaddam B, Skinner C, Skinner SA, Bernes S, Armstrong N, Shinawi M, Stankiewicz P, Patel A, Cheung SW, Lupski JR, Beaudet AL, Sahoo T: Microdeletion 15q13.3: a locus with incomplete penetrance for autism, mental retardation, and psychiatric disorders. J Med Genet 2009, 46 (6):382-388

43. Miller DT, Shen Y, Weiss LA, Korn J, Anselm I, Bridgemohan C, Cox GF, Dickinson H, Gentile J, Harris DJ, Hegde V, Hundley R, Khwaja O, Kothare S, Luedke C, Nasir R, Poduri A, Prasad K, Raffalli P, Reinhard A, Smith SE, Sobeih MM, Soul JS, Stoler J, Takeoka M, Tan WH, Thakuria J, Wolff R, Yusupov R, Gusella JF, et al: Microdeletion/duplication at 15q13.2q13.3 among individuals with features of autism and other neuropsychiatric disorders. J Med Genet 2009, 46(4):242-248.

44. Kumar RA, KaraMohamed S, Sudi J, Conrad DF, Brune C, Badner JA, Gilliam TC, Nowak NJ, Cook EH Jr, Dobyns WB, Christian SL: Recurrent 16p11.2 microdeletions in autism. Hum Mol Genet 2008, 17(4):628-638.

45. Shinawi M, Liu P, Kang SH, Shen J, Belmont JW, Scott DA, Probst FJ, Craigen WJ, Graham BH, Pursley A, Clark G, Lee J, Proud M, Stocco A, Rodriguez DL, Kozel BA, Sparagana S, Roeder ER, McGrew SG, Kurczynski TW, Allison LJ, Amato S, Savage S, Patel A, Stankiewicz P, Beaudet AL, Cheung SW, Lupski JR: Recurrent reciprocal 16p11.2 rearrangements associated with global developmental delay, behavioural problems, dysmorphism, epilepsy, and abnormal head size. J Med Genet 2010, 47(5):332-341.

46. Bijlsma EK, Gijsbers AC, Schuurs-Hoeijmakers JH, van Haeringen A, van de Putte DE Fransen, Anderlid BM, Lundin J, Lapunzina P, Pérez Jurado LA, Delle Chiaie B, Loeys B, Menten B, Oostra A, Verhelst H, Amor DJ, Bruno DL, van Essen AJ, Hordijk R, Sikkema-Raddatz B, Verbruggen KT, Jongmans MC,
Pfundt R, Reeser HM, Breuning MH, Ruivenkamp CA: Extending the phenotype of recurrent rearrangements of 16p11.2: deletions in mentally retarded patients without autism and in normal individuals. Eur J Med Genet 2009, 52(2-3):77-87.

47. Fernandez BA, Roberts W, Chung B, Weksberg R, Meyn S, Szatmari P, Joseph-George AM, Mackay S, Whitten K, Noble B, Vardy C, Crosbie V, Luscombe S, Tucker E, Turner L, Marshall CR, Scherer SW: Phenotypic spectrum associated with de novo and inherited deletions and duplications at $16 \mathrm{p} 11.2$ in individuals ascertained for diagnosis of autism spectrum disorder. J Med Genet 2010, 47(3):195-203.

48. Hanson E, Nasir RH, Fong A, Lian A, Hundley R, Shen Y, Wu BL, Holm IA, Miller DT: 16p11.2 Study Group Clinicians: Cognitive and behavioral characterization of 16p11.2 deletion syndrome. J Dev Behav Pediatr 2010, 31(8):649-657.

49. Hannes FD, Sharp AJ, Mefford HC, de Ravel T, Ruivenkamp CA, Breuning MH, Fryns JP, Devriendt K, Van Buggenhout G, Vogels A, Stewart H, Hennekam RC, Cooper GM, Regan R, Knight SJ, Eichler EE, Vermeesch JR: Recurrent reciprocal deletions and duplications of 16p13.11: the deletion is a risk factor for MR/MCA while the duplication may be a rare benign variant. J Med Genet 2009, 232(4):223.

50. Ingason A, Rujescu D, Cichon S, Sigurdsson E, Sigmundsson T, Pietiläinen OP, Buizer-Voskamp JE, Strengman E, Francks C, Muglia P, Gylfason A, Gustafsson O, Olason PI, Steinberg S, Hansen T, Jakobsen KD, Rasmussen HB, Giegling I, Möller HJ, Hartmann A, Crombie C, Fraser G, Walker N, Lonnqvist J, Suvisaari J, Tuulio-Henriksson A, Bramon E, Kiemeney LA, Franke $B$, Murray $R$, et al: Copy number variations of chromosome 16p13.1 region associated with schizophrenia. Mol Psychiatr 2011, 16(1):17-25.

51. Ullmann R, Turner G, Kirchhoff M, Chen W, Tonge B, Rosenberg C, Field M, Vianna-Morgante AM, Christie L, Krepischi-Santos AC, Banna L, Brereton AV Hill A, Bisgaard AM, Müller I, Hultschig C, Erdogan F, Wieczorek G, Ropers $\mathrm{HH}$ : Array CGH identifies reciprocal 16p13.1 duplications and deletions that predispose to autism and/or mental retardation. Hum Mutat 2007, 28(7):674-682

52. Ramalingam A, Zhou XG, Fiedler SD, Brawner SJ, Joyce JM, Liu HY, Yu S: 16 13.11 duplication is a risk factor for a wide spectrum of neuropsychiatric disorders. J Hum Genet 2011, 56(7):541-544.

53. Moreno-De-Luca D, Consortium SGENE, Mulle JG, Simons Simplex Collection Genetics Consortium, Kaminsky EB, Sanders SJ, Gene STAR, Myers SM, Adam MP, Pakula AT, Eisenhauer NJ, Uhas K, Weik L, Guy L, Care ME, Morel CF, Boni C, Salbert BA, Chandrareddy A, Demmer LA, Chow EW, Surti U, Aradhya S, Pickering DL, Golden DM, Sanger WG, Aston E, Brothman AR, Gliem TJ, Thorland EC, et al: Deletion $17 q 12$ is a recurrent copy number variant that confers high risk of autism and schizophrenia. Am J Hum Genet 2010, 87(5):618-630.

54. Loirat C, Bellanné-Chantelot C, Husson I, Deschênes G, Guigonis V, Chabane N: Autism in three patients with cystic or hyperechogenic kidneys and chromosome 17q12 deletion. Nephrol Dial Transplant 2010, 25(10):3430-3433.

55. Nagamani SC, Erez A, Shen J, Li C, Roeder E, Cox S, Karaviti L, Pearson M, Kang SH, Sahoo T, Lalani SR, Stankiewicz P, Sutton VR, Cheung SW: Clinical spectrum associated with recurrent genomic rearrangements in chromosome 17q12. Eur J Hum Genet 2010, 18(3):278-284.

56. Vorstman JA, Morcus ME, Duijff SN, Klaassen PW, Heineman-de Boer JA, Beemer FA, Swaab H, Kahn RS, van Engeland $H$ : The 22q11.2 deletion in children: high rate of autistic disorders and early onset of psychotic symptoms. J Am Acad Child Adolesc Psychiatr 2006, 45 (9):1104-1113.

57. Fine SE, Weissman A, Gerdes M, Pinto-Martin J, Zackai EH, McDonaldMcGinn DM, Emanuel BS: Autism spectrum disorders and symptoms in children with molecularly confirmed 22q11.2 deletion syndrome. J Autism Dev Disord 2005, 35(4):461-470.

58. Antshel KM, Aneja A, Strunge L, Peebles J, Fremont WP, Stallone K, Abdulsabur N, Higgins AM, Shprintzen RJ, Kates WR: Autistic spectrum disorders in velo-cardio facial syndrome (22q11.2 deletion). J Autism Dev Disord 2007, 37(9):1776-1786.

59. Kates WR, Antshel KM, Fremont WP, Shprintzen RJ, Strunge LA, Burnette CP, Higgins AM: Comparing phenotypes in patients with idiopathic autism to patients with velocardiofacial syndrome (22q11 DS) with and without autism. Am J Med Genet A 2007, 143A(22):2642-2650.

60. Niklasson L, Rasmussen P, Oskarsdóttir S, Gillberg C: Autism, ADHD, mental retardation and behavior problems in 100 individuals with $22 q 11$ deletion syndrome. Res Dev Disabil 2009, 30(4):763-773. 
61. Gothelf D: Velocardiofacial syndrome. Child Adolesc Psychiatr Clin N Am 2007, 16(3):677-693.

62. Shprintzen RJ: Velo-cardio-facial syndrome: 30 Years of study. Dev Disabil Res Rev 2008, 14:3-10.

63. Lo-Castro A, Galasso C, Cerminara C, El-Malhany N, Benedetti S, Nardone AM, Curatolo P: Association of syndromic mental retardation and autism with 22q11.2 duplication. Neuropediatrics 2009, 40(3):137-140.

64. Mukaddes NM, Herguner S: Autistic disorder and 22q11.2 duplication. World J Biol Psychiatr 2007, 8(2):127-130.

65. Ramelli GP, Silacci C, Ferrarini A, Cattaneo C, Visconti P, Pescia G: Microduplication 22q11.2 in a child with autism spectrum disorder: clinical and genetic study. Dev Med Child Neurol 2008, 50(12):953-955

66. Hassed S, Vaz SA, Lee J, Mulvihill JJ, Li S: Expanded phenotype of the 22q duplication syndrome. Am J Hum Genet 2004, 75:151. Suppl.

67. Ensenauer RE, Adeyinka A, Flynn HC, Michels W, Lindor NM, Dawson DB, Thorland EC, Lorentz CP, Goldstein JL, McDonald MT, Smith WE, Simon-Fayard E, Alexander AA, Kulharya AS, Ketterling RP, Clark RD, Jalal SM: Microduplication 22q11.2, an emerging syndrome: clinical, cytogenetic, and molecular analysis of thirteen patients. Am J Hum Genet 2003, 73(5):1027-1040.

68. Courtens W, Schramme I, Laridon A: Microduplication 22q11.2: a benign polymorphism or a syndrome with a very large clinical variability and reduced penetrance?-Report of two families. Am J Med Genet A 2008, 46A(6):758-763.

69. Ou Z, Berg JS, Yonath H, Enciso VB, Miller DT, Picker J, Lenzi T, Keegan CE, Sutton VR, Belmont J, Chinault AC, Lupski JR, Cheung SW, Roeder E, Patel A: Microduplications of 22q11.2 are frequently inherited and are associated with variable phenotypes. Genet Med 2008, 10(4):267-277.

70. Portnoï MF: Microduplication 22q11.2: a new chromosomal syndrome. Eur J Med Genet 2009, 52:88-93.

71. Cooper GM, Coe BP, Girirajan S, Rosenfeld JA, Vu TH, Baker C, Williams C, Stalker H, Hamid R, Hannig V, Abdel-Hamid H, Bader P, McCracken E, Niyazov D, Leppig K, Thiese H, Hummel M, Alexander N, Gorski J, Kussmann J, Shashi V, Johnson K, Rehder C, Ballif BC, Shaffer LG, Eichler EE: A copy number variation morbidity map of developmental delay. Nat Genet 2011, 9:838-846.

72. Sahoo T, Theisen A, Rosenfeld JA, Lamb AN, Ravnan JB, Schultz RA, Torchia BS, Neill N, Casci I, Bejjani BA, Shaffer LG: Copy number variants of schizophrenia susceptibility loci are associated with a spectrum of speech and developmental delays and behavior problems. Genet Med 2011, 13:868-880.

73. Skuse DH: Rethinking the nature of genetic vulnerability to autistic spectrum disorders. Trends Genet 2007, 23:387-395.

74. Crespi B: In In One hundred years of insanity: genomic, psychological, and evolutionary models of autism in relation to schizophrenia, Handbook of Schizophrenia Spectrum Disorders, Volume I. Edited by Ritsner M. New York: Springer; 2011:163-185

75. Addington J, Penn D, Woods SW, Addington D, Perkins DO: Social functioning in individuals at clinical high risk for psychosis. Schizophr Res 2008, 99:119-124.

76. Welham J, Isohanni M, Jones P, McGrath J: The antecedents of schizophrenia: a review of birth cohort studies. Schizophr Bull 2009, 35:603-623.

77. Gibson CM, Penn DL, Prinstein MJ, Perkins DO, Belger A: Social skill and social cognition in adolescents at genetic risk for psychosis. Schizophr Res 2010, 122:179-184.

78. Saracco-Alvarez R, Rodríguez-Verdugo S, García-Anaya M, Fresán A: Premorbid adjustment in schizophrenia and schizoaffective disorder. Psychiatr Res 2009, 165:234-240.

79. Remschmidt HE, Schulz E, Martin M, Warnke A, Trott GE: Childhood-onset schizophrenia: history of the concept and recent studies. Schizophr Bull 1994, 20:727-745.

80. Tandon R, Nasrallah HA, Keshavan MS: Schizophrenia, "just the facts" 4. Clinical features and conceptualization. Schizophr Res 2009, 110:1-23.

81. Frith CD, Frith U: Elective affinities in schizophrenia and childhood autism. In Social psychiatry: theory, methodology and practice. Edited by Bebbington P. New Brunswick, NJ: Transactions Press; 1991:65-88.

82. Goldstein G, Minshew NJ, Allen DN, Seaton BE: High-functioning autism and schizophrenia: a comparison of an early and late onset neurodevelopmental disorder. Arch Clin Neuropsychol 2002, 17:461-475.

83. Sheitman BB, Kraus JE, Bodfish JW, Carmel H: Are the negative symptoms of schizophrenia consistent with an autistic spectrum illness? Schizophr Res 2004, 69:119-120.
84. Tjordman S: Reunifying autism and early-onset schizophrenia in terms of social communication disorders. Behav Brain Sci 2008, 31:278-279.

85. King BH, Lord C: Is schizophrenia on the autism spectrum? Brain Res 2011, 1380:34-41.

86. Welch KA, Lawrie SM, Muir W, Johnstone EC: Systematic review of the clinical presentation of schizophrenia in intellectual disability. $J$ Psychopathol Behav Assess 2011, 33:246-253.

87. Lauritsen MB, Pedersen CB, Mortensen PB: The incidence and prevalence of pervasive developmental disorders: a Danish population-based study. Psychol Med 2004, 34:1339-1346.

88. Happé F: Criteria, categories, and continua: autism and related disorders in DSM-5. J Am Acad Child Adolesc Psychiatr 2011, 50:540-542.

89. Walker DR, Thompson A, Zwaigenbaum L, Goldberg J, Bryson SE, Mahoney WJ, Strawbridge CP, Szatmari P: Specifying PDD-NOS: a comparison of PDD-NOS, Asperger syndrome, and autism. J Am Acad Child Adolesc Psychiatr 2004, 43:172-180.

90. Sobin C, Blundell ML, Conry A, Weiller F, Gavigan C, Haiman C, Karayiorgou M Early, non-psychotic deviant behavior in schizophrenia: a possible endophenotypic marker for genetic studies. Psychiatr Res 2001, 101:101-113.

91. Baron-Cohen S, Lombardo MV, Auyeung B, Ashwin E, Chakrabarti B, Knickmeyer $\mathrm{R}$ : Why are autism spectrum conditions more prevalent in males? PLOS Biol 2011, 9:e1001081.

92. Bassett AS, Scherer SW, Brzustowicz LM: Copy number variations in schizophrenia: critical review and new perspectives on concepts of genetics and disease. Am J Psychiatry 2010, 167(8):899-914.

93. Vassos E, Collier DA, Holden S, Patch C, Rujescu D, St Clair D, Lewis CM: Penetrance for copy number variants associated with schizophrenia. Hum Mol Genet 2010, 19:3477-3481.

94. Cantor S, Evans J, Pearce J, Pezzot-Pearce T: Childhood schizophrenia: present but not accounted for. Am J Psychiatry 1982, 139:758-762.

95. Petty LK, Ornitz EM, Michelman JD, Zimmerman EG: Autistic children who become schizophrenic. Arch Gen Psychiatry 1984, 41(2):129-135.

96. Watkins JM, Asarnow RF, Tanguay PE: Symptom development in childhood onset schizophrenia. J Child Psychol Psychiatry 1988, 29:865-878.

97. Clarke DJ, LittleJohns CS, Corbett JA, Joseph S: Pervasive developmental disorders and psychoses in adult life. Br J Psychiatry 1989, 155:692-699.

98. Descheemaeker MJ, Vogels A, Govers V, Borghgraef M, Willekens D, Swillen A, Verhoeven W, Fryns JP: Prader-Willi syndrome: new insights in the behavioural and psychiatric spectrum. J Intellect Disabil Res 2002, 46:41-50.

99. Sporn AL, Addington AM, Gogtay N, Ordoñez AE, Gornick M, Clasen L, Greenstein D, Tossell JW, Gochman P, Lenane M, Sharp WS, Straub RE, Rapoport JL: Pervasive developmental disorder and childhood-onset schizophrenia: comorbid disorder or a phenotypic variant of a very early onset illness? Biol Psychiatry 2004, 55(10):989-994.

100. Padgett FE, Miltsiou E, Tiffin PA: The co-occurrence of nonaffective psychosis and the pervasive developmental disorders: a systematic review. J Intellect Dev Disabil 2010, 35:187-198.

101. Volkmar FR, Cohen DJ: Comorbid association of autism and schizophrenia. Am J Psychiatry 1991, 148:1705-1707.

102. Tsakanikos E, Costello H, Holt G, Bouras N, Sturmey P, Newton T: Psychopathology in adults with autism and intellectual disability. J Autism Dev Disord 2006, 36:1123-1129.

103. Rutter M: Genetic studies of autism: from the 1970s into the millennium. J Abnorm Child Psychol 2000, 28:3-14.

104. Skuse DH, Mandy WP, Scourfield J: Measuring autistic traits: heritability, reliability and validity of the Social and Communication Disorders Checklist. Br J Psychiatry 2005, 187:568-572.

105. Constantino JN, Zhang Y, Frazier T, Abbacchi AM, Law P: Sibling recurrence and the genetic epidemiology of autism. Am J Psychiatry 2010, 167:1349-1356.

106. Kendler KS, Neale MC, Walsh D: Evaluating the spectrum concept of schizophrenia in the Roscommon Family Study. Am J Psychiatry 1995, 152:749-754.

107. Lichtenstein P, Björk C, Hultman CM, Scolnick E, Sklar P, Sullivan PF: Recurrence risks for schizophrenia in a Swedish national cohort. Psychol Med 2006, 36:1417-1425.

108. Daniels JL, Forssen U, Hultman CM, Cnattingius S, Savitz DA, Feychting M, Sparen P: Parental psychiatric disorders associated with autism spectrum disorders in the offspring. Pediatrics 2008, 121:e1357-e1362.

109. Addington AM, Rapoport J: The genetics of childhood-onset schizophrenia: when madness strikes the prepubescent. Curr Psychiatr Rep 2009, 11:156-161. 
110. Chen YZ, Matsushita M, Girirajan S, Lisowski M, Sun E, Sul Y, Bernier R, Estes A, Dawson G, Minshew N, Shellenberg GD, Eichler EE, Rieder MJ, Nickerson DA, Tsuang DW, Tsuang MT, Wijsman EM, Raskind WH, Brkanac Z: Evidence for involvement of GNB1L in autism. Am J Med Genet B Neuropsychiatr Genet 2011, 159B:61-71.

111. Buitelaar JK, van der Gaag RJ: Diagnostic rules for children with PDD-NOS and multiple complex developmental disorder. J Child Psychol Psychiatry 1998, 39:911-919.

112. de Bruin El, de Nijs PF, Verheij F, Hartman CA, Ferdinand RF: Multiple complex developmental disorder delineated from PDD-NOS. J Autism Dev Disord 2007, 37:1181-1191.

113. Sprong M, Becker HE, Schothorst PF, Swaab H, Ziermans TB, Dingemans PM, Linszen D, van Engeland $\mathrm{H}$ : Pathways to psychosis: a comparison of the pervasive developmental disorder subtype Multiple Complex Developmental Disorder and the "At Risk Mental State". Schizophr Res 2008, 99:38-47.

114. Starling J, Dossetor D: Pervasive developmental disorders and psychosis. Curr Psychiatr Rep 2009, 11:190-196.

115. Dvir Y, Madaan V, Yakutis L, Frazier JA, Wilson DR: In Autistic spectrum disorders and schizophrenia, Handbook of Schizophrenia Spectrum Disorders, Volume I. Edited by Ritsner M. New York: Springer; 2011:143-162.

116. Sasson NJ, Pinkham AE, Carpenter KL, Belger A: The benefit of directly comparing autism and schizophrenia for revealing mechanisms of social cognitive impairment. J Neurodev Disord 2011, 3:87-100.

117. Solomon M, Olsen E, Niendam T, Ragland JD, Yoon J, Minzenberg M, Carter CS: From lumping to splitting and back again: Atypical social and language development in individuals with clinical-high-risk for psychosis, first episode schizophrenia, and autism spectrum disorders. Schizophr Res 2011, 131:146-151.

118. Werry JS: Child and adolescent (early onset) schizophrenia: a review in light of DSM-III-R. J Autism Dev Disord 1992, 4:601-624.

119. Kanner L: Autistic disturbances of affective contact. Nerv Child 1943, 2:217-250.

120. Asperger H: translated and annotated by Frith U. In [1944]. In Autistic psychopathy' in childhood, Autism and Asperger syndrome, Volume. Edited by Frith U.: Cambridge University Press; 1991:37-92.

121. Rutter M: Diagnosis and definition of childhood autism. J Autism Child Schizophr 1978, 8:139-161.

122. Itsara A, Cooper GM, Baker C, Girirajan S, Li J, Absher D, Krauss RM, Myers RM, Ridker PM, Chasman DI, Mefford H, Ying P, Nickerson DA, Eichler EE: Population analysis of large copy number variants and hotspots of human genetic disease. Am J Hum Genet 2009, 84(2):148-161.

123. Weiss LA, Shen Y, Korn JM, Arking DE, Miller DT, Fossdal R, Saemundsen E, Stefansson H, Ferreira MA, Green T, Platt OS, Ruderfer DM, Walsh CA, Altshuler D, Chakravarti A, Tanzi RE, Stefansson K, Santangelo SL, Gusella JF, Sklar P, Wu BL, Daly MJ: Autism Consortium: Association between microdeletion and microduplication at 16p11.2 and autism. N Engl J Med 2008, 358(7):667-675.

124. International Schizophrenia Consortium: Rare chromosomal deletions and duplications increase risk of schizophrenia. Nature 2008, 455(7210):237-241.

125. Stefansson H, Rujescu D, Cichon S, Pietiläinen OP, Ingason A, Steinberg S, et al: Large recurrent microdeletions associated with schizophrenia. Nature 2008, 455(7210):232-236.

126. Magri C, Sacchetti E, Traversa M, Valsecchi P, Gardella R, Bonvicini C, et al: New copy number variations in schizophrenia. PLoS One 2010, 5(10):e13422.

127. Schroer RJ, Phelan MC, Michaelis RC, Crawford EC, Skinner SA, Cuccaro M, et al: Autism and maternally derived aberrations of chromosome 15q. Am J Med Genet 1998, 76(4):327-336.

128. Veenstra-VanderWeele J, Cook EH Jr: Molecular genetics of autism spectrum disorder. Mol Psychiatr 2004, 9(9):819-832.

129. Bucan M, Abrahams BS, Wang K, Glessner JT, Herman El, Sonnenblick LI, et al: Genome-wide analyses of exonic copy number variants in a family-based study point to novel autism susceptibility genes. PLOS Genet 2009, 5(6):e1000536.

130. Rosenfeld JA, Coppinger J, Bejjani BA, Girirajan S, Eichler EE, Shaffer LG, et al: Speech delays and behavioral problems are the predominant features in individuals with developmental delays and 16p11.2 microdeletions and microduplications. J Neurodev Disord 2010, 2(1):26-38.

131. Jacquemont S, Reymond A, Zufferey F, Harewood L, Walters RG, Kutalik Z, et al: Mirror extreme BMI phenotypes associated with gene dosage at the chromosome 16p11.2 locus. Nature 2011, 478(7367):97-102.
132. Glessner JT, Reilly MP, Kim CE, Takahashi N, Albano A, Hou C, et al: Strong synaptic transmission impact by copy number variations in schizophrenia. Proc Natl Acad Sci U S A 2010, 107(23):10584-10589.

133. Prasad SE, Howley S, Murphy KC: Candidate genes and the behavioral phenotype in 22q11.2 deletion syndrome. Dev Disabil Res Rev 2008, 14(1):26-34.

134. Ogilvie CM, Moore J, Daker M, Palferman S, Docherty Z: Chromosome $22 q 11$ deletions are not found in autistic patients identified using strict diagnostic criteria. IMGSAC. International Molecular Genetics Study of Autism Consortium. Am J Med Genet 2000, 96(1):15-17.

135. Gothelf D, Schaer M, Eliez S: Genes, brain development and psychiatric phenotypes in velo-cardio-facial syndrome. Dev Disabil Res Rev 2008, 14(1):59-68.

136. In Velo-cardio-facial syndrome: a model for understanding microdeletion disorders. Edited by Murphy Kieran C, Scambler Peter J. Cambridge: Cambridge University Press; 2005.

137. Brunet A, Armengol L, Pelaez T, Guillamat R, Vallès V, Gabau E, et al: Failure to detect the 22q11.2 duplication syndrome rearrangement among patients with schizophrenia. Behav Brain Funct 2008, 4:10.

doi:10.1186/1866-1955-4-15

Cite this article as: Crespi and Crofts: Association testing of copy number variants in schizophrenia and autism spectrum disorders. Journal of Neurodevelopmental Disorders 2012 4:15.

\section{Submit your next manuscript to BioMed Central and take full advantage of:}

- Convenient online submission

- Thorough peer review

- No space constraints or color figure charges

- Immediate publication on acceptance

- Inclusion in PubMed, CAS, Scopus and Google Scholar

- Research which is freely available for redistribution 